\title{
The Soviet Union and the Iranian Revolution
}

How Experts, Intelligence Services and Politicians of the Two Superpowers Missed the Birth of Islamic Fundamentalism

Dmitry Asinovsky

\section{Abstract}

The 1978-1979 revolution in Iran remains a contentious issue among researchers. Opinions are still divided over its causes, driving forces, and background. Similar debates took place periodically on the eve of the revolution and immediately after it. Squeezed into the tight canonical framework of the Cold War era, Soviet experts and foreign policymakers faced the need to make some judgements on the events in Iran and shape the Soviet Union's attitude towards the new Iranian regime. This article examines why the official Soviet attitude towards the Iranian revolution and the new Iranian authorities remained quite benevolent throughout 1979-1983, even though the Ayatollah Khomeini-led clergy systematically tightened their grip on power. This article touches upon the way Soviet pundits regarded the situation in Iran in geopolitical terms from the standpoint of superpower rivalry. This article also relies on the experience of Soviet-Iranian relations in the previous decades, which bred certain stereotypes and expectations among the people responsible for making decisions.

Dmitry Asinovsky is a junior research fellow at the European University in St. Petersburg.

ORCID ID: 0000-0003-2108-7523

ResearcherID: 0-3294-2018

Тел.: +79219220783

E-mail: dasinovskiy@gmail.com ; dasinovsky@eu.spb.ru

European University in St. Petersburg

6/1, Litera A, Gagarinskaya st., St.-Petersburg 191187, Russia

Tel: +7 812 386-7637

DOI: $10.31278 / 1810-6374-2018-16-3-190-208$ 
Lastly, considerable attention is paid to the Marxist view of the nature of revolutions - in general and in the "Third World" in particular - which caused a tangible impact on how Soviet experts described the driving forces of the revolution and the future of the revolutionary movement in Iran.

Keywords: Iranian revolution, Soviet foreign policy, global Cold War, international pundits, the Third Word, Asian and African countries

"I would like to testify that in Soviet foreign policy of that period such a problem as fundamentalism did not exist at the practical level.

Nobody ever discussed this issue at Politburo or Foreign Ministry board meetings. It is true that at that time we did not regard it as a serious problem.

At least I do not recall a single document or resolution or discussion on fundamentalism in government circles."

Anatoly Dobrynin, Soviet ambassador to the United States (1962-1986)

"In the United States you knew more about Islamic fundamentalism than we did in the Soviet Union, because I do not think that at that time anybody explained to our leadership what an ayatollah was."

Karen Brutents, deputy chief of the International Section, the CPSU Central Committee (1976-1986)

T n September 1995, the Norwegian Nobel Institute arranged a symposium that brought together Soviet and U.S. Cold War veterans who had made political, military, and ideological decisions. Held at Oslo's historical Lysebu hotel, the meeting focused on the history of Soviet intervention in Afghanistan and the end of détente. Among those on the Soviet panel were former deputy chief of the International Section of the USSR Communist Party's Central Committee Karen Brutents and former USSR KGB station chief in Tehran and eventually head of the USSR KGB's First Department (foreign intelligence) Leonid Shebarshin. Both took an active part in formulating and im- 
plementing Soviet policy towards revolutionary Iran. It was there, at Lysebu, during the session devoted to the revolution in Iran and the superpowers' response to it, that the audience for the first time heard in public a number of viewpoints on the Soviet contribution to the Iranian revolution. Those disclosures would be repeatedly cited and discussed by researchers afterwards. It was at that session that Karen Brutents and former Soviet ambassador to the United States Anatoly Dobrynin made the statements chosen for the epigraph in this article (Savranskaya, Welch and Westad, 1996).

\section{ASIAN AND AFRICAN COUNTRIES VS. THIRD WORLD COUNTRIES}

Islamism. Political Islam. Islamic fundamentalism. The mass media and academic studies are literally brimming with these terms. Against the background of the radical Islamic movements of the 1990s-2010s, the Islamic regime in today's Iran seems much easier to understand (if not more moderate) at least because it is part of Iran's officialdom. However, what we see today as a natural component of international relations, in the 1970s-1980s was not just a new, but also an unheardof and inconceivable phenomenon in world politics. The revolution in Iran came as a bolt out of the blue for most pundits, including those who formulated foreign policy for the world powers. Sudden regime change was not very rare, though, particularly in the countries that the Soviet Union customarily referred to as "Asian and African countries," and the United States and Western Europe generally called "the Third World." In fact, just several years before the events in Iran, an unexpected government turnover in Ethiopia had forced the Soviet Union to sever its long-time alliance with Somalia, thus losing a naval base on the Red Sea in order to prop up Mengistu's newly-established proSoviet regime. What made the Iranian revolution so special was not its unexpectedness, but the forces that led it and eventually formed Iran's new government.

The idea of religion as an exclusive element of traditional, premodern society was a key element of both liberal democratic and Marxist ideology. The postulate stating that history develops in a revolutionary manner under the leadership of progressive forces is an even more 
important ideological component of liberal theory and the theory of Marxism in particular. In this ideological context, the Islamic revolution narrative that Ayatollah Ruhollah Khomeini proposed immediately after his return to Iran in February 1979 had no chance of being interpreted seriously in the U.S. and still less so in the Soviet Union.

In his statement at the Lysebu symposium, Shebarshin stressed the idea that the events in Iran deserved no other name than "popular revolution" (Savranskaya, Welch and Westad, 1996). In this respect Shebarshin fully agreed with his U.S. counterparts. The revolution in Iran was actually a result of a mass popular movement against the Shah's regime, but what made millions of demonstrators take to city streets across Iran and what was their vision for Iran's future? For nearly forty years Iranian historians have been probing into the causes and nature of the revolution. Was that revolution truly Islamic and what is an "Islamic revolution?" Or were the Islamic slogans a cover-up masking the social or anti-Western nature of a quite secular modern movement (Keddie, 1983; Arjomand, 1986; Fischer, 2003; Kurzman, 2004; Abrahamian, 2009)? Having no purpose or competence to participate in such a discussion, in this survey we will review the opinions of people who were asking precisely these questions during the events in Iran. The sole difference is that those people were expected to formulate the opinion of one of the superpowers.

The role of the leader of the world revolution invariably took center stage in Soviet ideology. The Soviet Union in World War II and its spreading influence in Eastern Europe provided far stronger backing for the country's ambitions of a leader than ever before. Joseph Stalin's death and Nikita Krushchev's rise to power, which occurred in parallel to the world decolonization trend, made it possible to expand the scene of the Cold War confrontation and to change the Soviet Union's attitude towards anti-colonial national movements in the former colonies and newly-independent countries, thus turning superpower rivalry in Europe into what in historiography is commonly referred to as the global Cold War (Westad, 2005; Fursenko and Naftali, 2007; Taubman, 2004). The Soviet Union wanted to attract newly-decolonized Asian and African countries to its side, a 
desire that brought about the emergence of new foreign policy instruments. For instance, Central Asia's Soviet intellectuals were used as mediators in communication with the cultural elites of Asian and African countries in order to overcome the prejudice towards the Soviet Union as another colonial power in no way different from Western European countries (Kirasirova, 2011; Kalinovsky, 2013). Soviet initiatives suffered a number of strategic failures in Asian and African countries (the defeat of Gamal Abdel Nasser and his allies in the Six-Day War and the refusal of Egypt's new President Anwar Sadat to cooperate with the Soviet Union, the General Suharto-led coup in Indonesia, the overthrow of the Salvador Allende government in Chile, and the ideological split with China, which was the most painful of all). Yet in early 1970, the Soviet Union believed that the Marxist laws of history had finally been set in motion and the Third World was moving along the Soviet path of development (Zubok, 2009; Friedman, 2015; Yordanov, 2016).

This illusion stemmed from a string of political transformations in the developing world that were interpreted as a result of successful Soviet foreign policy. When the last British soldier was evacuated from Aden in 1971, ultra-left Marxist rebels rose to power in South Yemen. In 1975, after a decade of bloody war in Indochina, the last American troops were leaving Saigon, which was about to surrender to the army of Communist North Vietnam. In 1976, the forces of the Marxist People's Movement for the Liberation of Angola marched into Luanda with Soviet and Cuban support. Two years before that the proSoviet left-wing radical party FRELIMO took power in Mozambique, another former Portuguese colony in southern Africa. In 1977-1978, opposite South Yemen, on the other side of the Bab-el-Mandeb Strait, a centuries-old monarchy fell in Ethiopia and the pro-Soviet party Derg under Mengistu Haile Mariam took over. And in mid-1979, leftist radicals of the Sandinista National Liberation Front, supported by the Soviet Union and Cuba, came to power in Nicaragua after a prolonged civil war.

The revolution in Iran seemed a logical step in this series of what looked like Soviet foreign policy successes. The Shah of Iran, a reliable 
U.S. ally and "regional policeman" in accordance with the Nixon doctrine, was overthrown by a mass popular movement. However, in reality the Iranian revolution was one of the first signals heralding the collapse of the international system of détente. Yet it did not fit in with the Soviet theory of revolutions and looked very different from the customary pattern of revolutions in Asia and Africa. The Soviet Union took an officially friendly attitude towards the new revolutionary regime and the newly-established Islamic republic. Even in 1983, when Iran's left-wing movement (which could be considered as one of the factors of support for the revolution by the Soviet Union) was wiped out and an outspokenly theocratic system of power was established in Iran, Soviet analysts kept publishing works that described the Islamic republic as a "progressive anti-imperialist force, which managed to overthrow the Shah's despotic, feudal regime" (Aliev, 1980; Agayev, 1981; Reznikov 1983).

On November 19, 1978, Pravda's front page carried a statement by Soviet Communist Party leader Leonid Brezhnev. The essence of the Soviet Union's position boiled down to just one word-non-interference (Pravda, 1978). By November 1978 the social and political crisis had lasted for nearly a year and was generally seen by experts and decision-makers in the Soviet leadership as a tiny piece of the global puzzle, where Iran was one of the many scenes of ideological confrontation between the two superpowers. In his statement Brezhnev cautioned any foreign force against intervention in Iran's internal affairs. That statement fitted in well with the general public rhetoric in the Soviet mass media in the previous months and certainly influenced the official stance taken later. Many Soviet newspapers, magazines, and television and radio broadcasts presented to their readerships and audiences not only a description of the latest events in Iran, but also a retrospective analysis of the historical context. Soviet authors paid special attention to the 1953 military coup against the Iranian government of Dr. Mohammad Mossadegh, which the CIA had plotted and staged. Such unequivocal attention to this period in Iran's recent history in a given group of publications and messages pointed to the similarity of the current situation and the events of twenty-five years ago. 
The main fear of Soviet experts and politicians was that there might be a replay and the popular movement in Iran could be suppressed by the U.S. In the Cold War realties of that time, this kind of Soviet opinion may look quite natural, but it should be remembered that this "popular uprising" eventually developed into a revolution that was very different from what the Soviet experts had read about in the canonical works on historical materialism.

\section{REGIONAL REALPOLITIK OF THE 1970s}

The history of Soviet-Iranian relations in the postwar period remains greatly underexplored in scholarly research, which focuses mostly on the events of 1946 and the crisis in Iranian Azerbaijan (Yegorova, 1996; Raine, 2001; Hasanli, 2006; Fawcett, 2014). Yet it was during this period that Soviet-Iranian relations underwent a number of significant changes. The common border and the Soviet Union's traditional geopolitical interests in the region were the main factors for Soviet activity in Iran after the pullout of troops in May 1946. Furthermore, the Iranian Majlis refused to ratify the treaty on oil concessions at the end of 1946. The Tudeh (People's) Party of Iran remained the main campaigner for Soviet interests. However, in 1949 the party was outlawed in Iran on the pretext of alleged participation in an attempt on the Shah's life. Towards the beginning of 1950s the Soviet Union's ability to influence the situation in Iran had shrunk considerably. At that moment some crucial changes occurred inside Iran as the Dr. Mohammad Mossadegh-led National Front rose to power. The attempt to nationalize the oil industry and the U.S. and British secret services-engineered coup that followed turned out to be not just key events in Iran's history in the twentieth century, but also crucial factors for the Soviet leadership's perception of the future internal political situation in Iran, including during the 1978-1979 revolution. For all students of Iranian history in the twentieth century this event is the most important focal point (alongside the revolution of 1978-1979 itself), but, as follows from Soviet academic publications from the 1970s, it was no less important at that time as well (Gasiorowski, 2004; Byrne, 2004; Abrahamian, 2013; Gasiorowski, 2013). Today we have a trustworthy picture of the march of events and, 
even more important, the fact that the CIA officially confirmed its role in staging the coup (Byrne, 2013). In the 1970s this question remained a matter of speculation, actively used by Soviet researchers and at the same time shaped their understanding of the role of the U.S. and Iranian nationalism in Iran's domestic policy.

It is noteworthy that when he held the post of Iran's prime minister, Dr. Mossadegh was by no means regarded in the Soviet Union as a friendly figure or as a potential ideological ally. His role in preventing the Soviet Union from obtaining oil concessions in northern Iran in 1944 and his "nationalist bourgeois program" in general played a considerable role in the Soviet foreign policy elite's rather negative view of the Iranian prime minister. Even his nationalization program, which by all odds should have attracted the Soviet leaders as an element of the anti-imperialist struggle with Britain, was interpreted not as a step taken for the sake of the country's national interests, but as part of Mossadegh's deal with the U.S., a country that many hoped would take Britain's place in Iran (Kalinovsky, 2014). Overall, the Soviet Union's attitude to Mossadegh's Iran was neutral. After unsuccessful attempts to take commanding positions in Iran at the end of World War II, Soviet foreign policy-makers painstakingly steered clear of direct intervention in Iran's affairs. The Soviet Union did not provide any special support for Mossadegh either during his premiership or after he was ousted from power. However, at a certain point in the mid-1950s his image in the Soviet Union began to change considerably. Once a potential ally of U.S. imperialists, Mossadegh started to be seen as a symbol of struggle for national liberation against crafty imperialist powers.

To a large extent this change of opinion was caused by the Soviet Union's above-mentioned global turn towards Asian and African countries. In the second half of the 1950, the Soviet leadership and Nikita Khrushchev himself made several attempts to establish relations with Mohammad Reza Shah. In 1956 the Shah of Iran made his first historical visit to the Soviet Union, a mere four months after Khrushchev's secret report to the Twentieth Congress of the Communist Party. This search for compromises and neighborly relations with 
Iran are unequivocally attributed to the creation of the Baghdad Pact, in which Iran assumed the key role (Zubok, 2009). Oddly enough, these attempts to find a common language with the Shah proceeded in parallel with the ideological rehabilitation of his arch political rival Mossadegh. The decision to refrain from supporting Mossadegh during the coup was among the charges put forward against Vyacheslav Molotov at the plenary meeting of the Communist Party's Central Committee of 1957, which exposed what was described as an "antiparty group." Molotov, who regained control of foreign policy after Stalin's death, shared Stalin's opinion that the revolutionary situation in Iran was hopeless. However, by 1957 the situation had changed and the refusal to support Mossadegh was interpreted as an incriminating act and betrayal of the interests of the global anti-colonial movement (Zubok, 1995).

At the same time, these multi-vectored initiatives provide the clue as to why the secret negotiations in 1959 failed to establish a friendly relationship with the Shah. Negotiations launched with the aim of concluding a non-aggression pact eventually came to a dead end due to the Shah's reluctance to trigger a conflict within the Baghdad Pact, which such a treaty would contradict. When the negotiations failed, the U.S.-inspired coup against Mossadegh became an important argument in the Soviet Union's anti-Shah propaganda targeting Iran. Incidentally, even after 1962, when relations with Tehran became stable again and the propaganda campaign was curtailed, Mossadegh as the national leader remained the chief figure to whom all Soviet commentators and students of Iran's recent history and modern politics referred (Alvandi, 2014a; 2014b).

After tensions began to ease in Soviet-Iranian relations in 1962, rapid economic and trading rapprochement became the key aspect of cooperation between the two countries. Growing trade, common infrastructural projects, and economic cooperation in the Caspian Sea were factors that benefited both sides economically and strengthened the political basis of bilateral relations. By the end of the 1970s, the Soviet Union and Iran were working on more than 150 joint farming and industrial projects, including the Trans-Caucasus gas pipeline, which 
enabled the Soviet Union to sell more gas to Eastern Europe, thereby increasing its hard currency revenues (Atkin, 1981).

The White Revolution launched by the Shah in 1963 drew a favorable response and comments from the Soviet Union as a movement that broke traditional feudal relations in Iranian society and opened up the prospect for "democratic progressive development." The Soviet press described the Iranian reforms as "an attempt at a breakthrough from feudalism to capitalism with the proletariat's growing role in a traditional agrarian society, a decline in the political influence of major land owners and an intensification of the class struggle" (Pravda, 1963). Significantly, such comments disagreed with the official stance of the Tudeh Party, at that moment in exile in East Berlin. The Tudeh-controlled Peik-e Iran radio station broadcasting to Iran from Bulgaria was strongly critical of the Shah's reforms as insufficient and deceitful. Under Soviet pressure, the Bulgarian leadership first suspended the broadcasts and then closed down Peik-e Iran until 1978, when the radio station went on the air again (Yodfat, 1983).

While economic relations between Iran and the Soviet Union remained extremely favorable, the Soviet Union's vision of the pollical transformations of the Iranian regime by the beginning of the 1970s was no longer as optimistic as it was in 1962-1963. The Shah was increasingly determined to make Iran a key regional power fitting in with the Nixon doctrine and relying on a long-term alliance with the United States (Alvandi, 2014c). This trend could not but make the Soviet Union feel certain concerns. The Shah's regional ambitions manifested themselves most graphically in Soviet-leaning South Yemen and Iraq. In 1971, the Shah sent commando units to Oman to provide support in suppressing the South Yemen-backed revolution in Dhofar Province (Goode, 2014) and in 1975 he was close to an open conflict with Iraq over disputed islands in the Shatt al-Arab. Also, since 1971 the Shah had managed to establish and strengthen relations with the Soviet Union's two strategic opponents. At the regional level the Shah stepped up cooperation with Egypt precisely when President Anwar Sadat severed friendly relations with the Soviet Union and expelled 
all Soviet advisers. It should be noted that Sadat's very close personal relations with the Shah lasted until the Iranian monarch's death. It was in Egypt that the exiled Shah's body was buried after a special ceremony, arranged in strict accordance with the rules of a state funeral. Iran's other newly-acquired partner in those years was China-a far more serious opponent of the Soviet Union on the global stage. The Shah established diplomatic relations with China in 1971. Although no upsurge in bilateral cooperation ensued, this sent a clear message to the Soviet Union and to a greater extent to the U.S. Washington remained the Iranian monarch's main strategic ally and, as the Iranian economy grew, in particular after the oil crisis of 1973, as a major provider of military hardware for the Iranian army. Soaring oil prices had the strongest effect on the Shah's certainty about Iran's prospects as a regional power and enabled him to start large-scale arms purchases overseas, which was another reason for the Soviet Union to criticize the Shah's regime.

And still, in the mid-1970s the Soviet Union saw the prospects for an upturn of the revolutionary movement in Iran as rather slim and limited. Iran's left-wing movement during that period essentially did not exist. The Tudeh Party had been outlawed for twenty-five years. Its leaders tried to influence Iranian policy, but most of them were either in exile in the Soviet Union or in other Eastern European countries. More radical and popular leftist movements, such as Mojahedin-e Khalq (People's Mojahedin Organization of Iran) were poorly organized, disunited, and unable to stage anything more serious than rare, sporadic terrorist attacks. Whereas later, with the beginning of the revolution, such movements as Mojahedin-e Khalq saw an influx of young supporters and, by and large, growing mass support. Yet the Tudeh Party, the actor on Iran's political scene that was closest to the Soviet Union, continued to experience problems (Yodfat, 1983; Atkin, 1981).

\section{THE REVOLUTION HAS A BEGINNING...}

Apparently, the role of the clergy in Iran was still less clear for a wide range of experts. A clear illustration of this can be found in an autumn issue of the New Times magazine, the first Soviet publication 
to mention Ayatollah Ruhollah Musavi Khomeini: “The strongest group opposed to the Shah, wrote the New York Times, consists of Muslim traditionalists loyal to Ayatollah Mohammed (sic!) Khomeini, a religious figure who has lived in Iraq in exile since 1963, when he organized a nation-wide movement against the land reform and the Shah's other modernization measures" (Kapikrayan and Ulyanskiy, 1978).

To do justice to the Soviet authors, it should be noted that in their review of the foreign press they cited word for word a June article in the New York Times, in which the future leader of the Iranian revolution was misnamed (Gage, 1978). However, instead of using such a good opportunity to point to the incompetence of their counterparts overseas, the Soviet commentators in fact followed in their footsteps. This seemingly minor, insignificant episode is very telling in that on both sides of the Atlantic analysts were equally ignorant of the real situation in Iran. Both the New York Times and the New Times lacked specialists who might have pointed to an obvious mistake in the name of one of Iran's prominent religious figures, so it hardly makes sense to ask how well they were informed about the ideological basics of new Islamic politicians. In his New Year's Eve speech in Tehran on December 31, 1977, U.S. President Jimmy Carter described Iran as an island of stability in the Middle East. These symbolically systematic mistakes in Soviet and U.S. public statements are a sure sign that Carter's festive toast might have well been echoed by his Soviet counterparts. The fact that U.S. journalists in June and Soviet ones in November still knew very little about the key figures in Iran's religious opposition is in a sense more telling than Carter's gross misjudgment voiced on the eve of 1978 .

As events in Iran followed their course in the 1970s-1980s, the Soviet Union's attitude to the revolution and the new Iranian regime changed. Concern and skepticism about the possibility of changes in the first half of 1978 gave way in the fall and winter of 1978 to the fear that the U.S. might decide to intervene to prevent the collapse of the Iranian monarchy. Whereas these fears persisted and played a decisive role for quite some time, in early 1979 it seemed that the revolution 
(which looked like an accomplished fact) caused the Soviet leaders and experts to hope that left-wing forces, above all the Tudeh Party, would soon intercept the initiative. Although nothing of the sort happened, the Soviet Union continued to provide support for the revolutionary regime in Iran, even after the beginning of the operation in Afghanistan, which caused an upsurge in anti-Soviet sentiment in the Iranian leadership and society. Only the total defeat of Iran's left-wing movement and the trial of the Tudeh Party caused a cooling and eventual freeze in Soviet-Iranian relations. At the same time, in academic circles and among experts, the revolution in Iran and the regime that took shape continued to be regarded in rather positive terms even after 1983-1984.

A number of factors can be used to explain this rather odd attitude of Soviet leaders and experts towards Iranian events. Firstly, day-today control of Soviet foreign policy towards Iran was the responsibility of the Foreign Ministry and the International Department of the Communist Party's Central Committee. For instance, the man responsible for the Iranian track at the Communist Party's International Department was Rostislav Ulyanovskiy. An old-time Bolshevik who had matured as a specialist on international affairs within the Communist International, Ulyanovskiy was quite consistent and dogmatic in his ideological interpretation of the revolutionary movement in Iran. Ulyanovskiy believed that the situation in Iran was consonant with the concept of a non-capitalist way of development, which postulated a quick transition from decolonizing, semi-feudal systems that were shrugging off imperialist dependence to building socialism. The documents at our disposal and memoirs testify that the International Department of the CPSU Central Committee in fact commanded the Tudeh Party and used the KGB station in Tehran as a channel to maintain communication and provide financial support for Tudeh (Ulyanovskiy, 1982, 1984). Confirmation of this can be found in the memoirs of former KGB station chief in Tehran Leonid Shebarshin (Shebarshin, 1996), his subordinate and eventually defector to the West Vladimir Kuzichkin (Kuzichkin, 1990), and documents from Vasily Mitrokhin's archive (Mitrokhin, n.d.). 
To a large extent Ulyanovskiy embodied the ideological approach to foreign policy. The fact that he was responsible for the Iranian track largely determined the great influence of ideology on Soviet decisions. However, this does not mean that the Soviet approach was devoid of pragmatism altogether. For instance, according to Leonid Shebarshin's memoirs, KGB chief Yuri Andropov, one of the top officials in the inner circle who made foreign policy decisions, had no faith that the revolution would proceed according to Soviet templates. It should be noted, though, that according to the same source, Andropov made such forecasts based on works by Karl Marx; in other words, to a certain extent from ideological, and not pragmatic positions (Shebarshin, 1996). Andropov's pragmatic view was that Iran, even with religious leaders at the helm, had dropped out of the group of U.S. allies. In this context, the worst that Andropov and his entourage feared was that the U.S. would be looking for a way to change this situation. In this sense, the seizure of hostages in the U.S. embassy and the acute crisis in Iranian-U.S. relations on the one hand was perceived in the Soviet Union with cautious optimism, but on the other hand was a reason for deep concern. Even in 1995, in his statement at the meeting in the Lysebu hotel, Shebarshin, in defiance of protests from his U.S. counterparts, claimed he had proof that the United States' abortive attempt to free its hostages in 1980 was in reality an operation with more far-reaching aims, including a change of power in Iran (Savranskaya, Welch and Westad, 1996).

\section{LEARNING FROM PAST MISTAKES?}

These permanent fears of U.S. intervention provide another argument that explains the Soviet Union's systematic support for the Islamic regime, even when this obviously contradicted ideological and pragmatic reasons. Generals always get ready to fight the last war. It is no accident that the events of 1953 and the coup that the British and U.S. secret services staged against the government of Mohammad Mossadegh were so frequently discussed in the Soviet media and analytical surveys. The Soviet leaders regarded the mode of action their predecessors had opted for in 1953 as an unforgivable mistake. Instead of 
intervening and supporting Mossadegh's anti-imperialist, albeit not pro-Soviet, government, the Soviet Union preferred to remain an idle onlooker in a situation where the U.S had managed to safeguard its geopolitical interests in Iran. This mistake was acknowledged and criticized, although behind closed doors during Nikita Khrushchev's rule. Now that an anti-imperialist, although not pro-Soviet, government had risen to power in Iran, the Soviet leaders were keen to avoid making the same mistakes again.

The decision to send Soviet troops to Afghanistan greatly affected the balance of Soviet-Iranian relations. On the one hand, it drew a strongly negative response from Tehran. And although the firmest supporters of a hard line towards the Soviet Union under Foreign Minister Sadegh Gotbzadeh were barred from power, the Soviet intervention in Afghanistan provided more fuel for Ayatollah Khomeini's foreign policy rhetoric that slammed the Soviet Union as a small Satan. On the other hand, the beginning of the Afghan war triggered an upsurge in activity towards Islam as a significant factor in political life. Although most Soviet analysts preferred to take a rather conservative approach to deny Islam as a political factor, the minutes at various roundtable meetings that brought together foreign policy pundits and experts on oriental affairs in 1979-1981 present a very different picture. Among Soviet experts there were enough people who said it was a great problem that Islam was still poorly studied as a political force and pointed to the revolution in Iran as clear proof running counter to the Soviet Union's official public stance, which reflected the point of view of the CPSU Central Committee's International Department (RGANI, n.d.; ARAN, n.d.). Quite noteworthy in this respect was a discussion between Georgy Mirsky and Yevgeny Primakov. They eventually agreed that support for the Ayatollah Khomeini-led revolution was a mistake fraught with the collapse of the left-wing movement in Iran and harmful to the Soviet Union's interests (ARAN, 1981).

However, these opinions were barely heard by the people responsible for making decisions. Against the backdrop of the Afghan events and the internal political crisis into which the Soviet Union was slid- 
ing, the Iranian problem and with it the problem of studying political Islam in fact had disappeared from the current Soviet foreign policy agenda. When Anatoly Dobrynbin told the conference at Lysebu that there had been no debate inside the Soviet leadership over Islamic fundamentalism and that this term did not exist as such, he was speaking the truth. The Soviet leadership preferred to turn a blind eye to that problem, leaving it to future generations to solve.

\section{References}

Abrahamian, E., 2009. The crowd in the Iranian revolution. Radical History Review, 2009 (105), pp. 13-38.

Abrahamian, E., 2013. The coup 1953: the CIA and the roots of modern U.S.Iranian relations. New York: The New Press.

Agaev, S., 1981. Iran $v$ proshlom $i$ nastoiastchem [Iran in the past and the present]. Moscow: Nauka.

Aliev, S., 1980. Problemy politicheskogo razvitiia Irana [Problems of political development in Iran]. Aziya i Afrika segodnya, 11.

Alvandi, R., 2014a. Flirting with neutrality: the Shah, Khrushchev, and the failed 1959 Soviet-Iranian negotiations. Iranian Studies, 47(3), pp. 419-440.

Alvandi, R., 2014b. The Shah's détente with Khrushchev: Iran's 1962 missile base pledge to the Soviet Union. Cold War History, 14(3), pp. 423-444.

Alvandi, R., 2014c. Nixon, Kissinger and the Shah in the Cold War. Oxford; New York: Oxford University Press.

ARAN, n.d., Spravka ob izuchenii v 1980 godu v nauchnykh uchrezhdeniyakh AN SSSR i AN soyuznykh respublik sovremennykh problem islama [A memorandum on research of contemporary problems of Islam in academic institutions of the USSR Academy of Sciences and Union Republican Academies of Sciences in 1980]. ARAN, F. 1731 Op. 1 D. 320 L. 32, Moscow.

ARAN, 1981. Stenogramma zasedaniya sektsii vneshney politiki Nauchnogo soveta po ekonomicheskim, politicheskim i ideologicheskim problemam Soedinennykh Shtatov Ameriki po teme "Politika SShA na Blizhnem Vostoke" [Notes of Proceedings of the Academic Board on the Economic, 
Political, and Ideological Problems of the United States Section on Foreign Policy. Agenda: "U.S. policies in the Middle East"]. ARAN F. 2113 Op. 1 D. 29 L. 45-49, Moscow.

Arjomand, S., 1986. Iran's Islamic revolution in comparative perspective. World Politics, 38(03), pp. 383-414.

Atkin, M., 1981. The Kremlin and Khomeini. Washington Quarterly, 4(2), pp. 50-67.

Byrne, M., 2004. The road to intervention: factors influencing U.S. policy toward Iran, 1945-1953. In: M. Gasiorowski and M. Byrne, eds. Mohammed Mossadeq and the 1953 Coup in Iran. Syracuse, NY: Syracuse University Press, pp. 201-226.

Byrne, M., 2013. CIA confirms role in the 1953 coup. The National Security Archive. [online] Available at: <https://nsarchive2.gwu.edu/NSAEBB/ NSAEBB435/> [Accessed 16 February 2017].

Fawcett, L., 2014. Revisiting the Iranian crisis of 1946: How much more do we know? Iranian Studies, 47(3), pp. 379-399.

Fischer, M., 2003. Iran: from religious dispute to revolution. Madison: University of Wisconsin Press.

Friedman, J., 2015. Shadow Cold War: the Sino-Soviet competition for the Third World. Chapel Hill: University of North Carolina Press.

Fursenko, A. and Naftali, T., 2007. Khruschev's Cold War: the inside story of an American adversary. New York: W.W. Norton \& Company.

Gage N., 1978. Shah of Iran faces challenge headed by Moslem clergy. The New York Times, 4 June, p.1.

Gasiorowski, M., 2004. The 1953 coup d'etat against Mossadeq. In: M. Gasiorowski and M. Byrne, eds. Mohammed Mossadeq and the 1953 coup in Iran. Syracuse, NY: Syracuse University Press, pp. 227-260.

Gasiorowski, M., 2013. The CIA TPBEDAMN Operation and the 1953 coup in Iran. Journal of Cold War Studies, 15(4), pp. 4-24.

Goode, J., 2014. Assisting our brothers, defending ourselves: the Iranian intervention in Oman, 1972-75. Iranian Studies, 47(3), pp. 441-462. 
Hasanli, J., 2006. SSSR-Iran: azerbaidzhanskii krizis $i$ nachalo kholodnoi voiny (1941-1946) [USSR-Iran: the Azerbaijan crisis and the beginning of the Cold War (1941-1946)]. Moscow: Geroi Otechestva.

Kalinovsky, A., 2014. The Soviet Union and Mossadeq: a research note. Iranian Studies, 47(3), pp. 401-418.

Keddie, N., 1983. Iranian revolutions in comparative perspective. The American Historical Review, 88(3), pp. 579-598.

Kurzman, C., 2004. The unthinkable revolution in Iran. Cambridge, Mass.: Harvard University Press.

Kuzichkin, V., 1990. Inside the KGB: my life in Soviet espionage. New York: Pantheon Books.

Mitrokhin, V. (n.d.). KGB v Irane [KGB in Iran]. [Manuscript] Cambridge University Churchill College Archive, MITN. Cambridge.

Pravda, 1963.

Pravda, 1978. Otvet L.I. Brezhneva na vopros korrespondenta "Pravdy" [Leonid Brezhnev answers the question of the Pravda correspondent], 19 November, p.1. Raine, F., 2001. Stalin and the creation of the Azerbaijan Democratic Party in Iran, 1945. Cold War History, 2(1), pp. 1-38.

Reznikov, A., 1983. Iran: padeniye shakhskogo rezhima [Iran: the fall of Shah's regime]. Moscow: Nauka.

RGANI, n.d. Ob itogakh raboty kruglogo stola "Aktualnye problemy izucheniya sovremennogo islama" [On the results of the roundtable discussion "Current problems in modern Islamic studies"]. (n.d.). RGANI, F. 5 Op. 76 D. 255 L. 3, Moscow.

Savranskaya, S., Welch, D. and Westad, O., 1996. The intervention in Afghanistan and the fall of détente. Oslo: Norwegian Nobel Institute, pp.39, 49, 54, 96.

Shebarshin, L., 1996. Ruka Moskvy: zapiski nachalnika sovetskoy razvedki [Russian connection: memoirs of a Soviet intelligence chief]. Moscow: Terra.

Ulyanovsky, R., 1982. Iranskaia revolutsiia i yeyo osobennosti [Iranian revolution and its characteristics]. Kommunist, (10).

Ulyanovsky, R., 1984. Postanovlenie Sekretariata TsK KPSS “O pros`be rukovodstva Narodnoy Partii Irana" [Resolution of the Secretariat of the Central Committee of the CPSU "On request from the Tudeh arty of Iran"]. Vladimir 
Bukovsky achive. [online] Available at: http://www.bukovsky-archives.net/pdfs/ terr-wd/ter84-5.pdf [Accessed 7 Jun. 2018].

Westad, O., 2005. The Global Cold War: Third World interventions and the making of our times. Cambridge: Cambridge University Press.

Yegorova, N., 1996. The "Iran crisis" of 1945-46: a view from the Russian archives. Cold War international history project. Woodrow Wilson International Center for Scholars, pp. 23-24.

Yodfat, A., 1983. The Soviet Union and revolutionary Iran. London: Croom Helm, pp. 44-45.

Yordanov, R., 2016. The Soviet Union and the horn of Africa during the Cold War: between ideology and pragmatism. Lanham: Lexington Books.

Zubok, V., 1995. Soviet intelligence and the Cold War: the "small" Committee of Information, 1952-53. Diplomatic History, 19(3), pp. 453-472.

Zubok, V., 2009. A failed empire: the Soviet Union in the Cold War from Stalin to Gorbachev. Chapel Hill: University of North Carolina Press, pp. 109-110. 